\title{
Water Resources, Environment and Sustainable Development in Nigeria
}

\author{
Christopher O. Orubu \\ Department of Economics, Delta State University, Abraka, Nigeria \\ E-mail: corubu@yahoo.com
}

KEYWORDS Water Resources. Environment. Development

\begin{abstract}
This paper examines the twin problems of water resources availability and access in Nigeria as well as the intricate relationship that exists between their exploitation, use and availability on the one hand, and environmental sustainability on the other. Access to water for different use categories is assessed to be relatively low in the country, even though there are indications of marginal improvement since the advent of a new democratic dispensation. A logical and comprehensive policy framework that integrates sound principles of water management, environmental sustainability and development can only more appropriately address the situation.
\end{abstract}

\section{INTRODUCTION}

Water resources can be broadly grouped into two categories - freshwater and marine water resources respectively. Freshwater resources consist of rivers and their plains, streams, lakes, wetlands and underground water reservoirs. Rainfall can also be grouped under freshwater resources - although man has no influence over its availability. On the other hand, marine water resources include lagoons, seas and the oceans. Sustainable welfare of man and indeed, all living things on earth depend on the wise and safe use of water. Freshwater resources provide the main source of safe drinking water for the human population, and also support agricultural activities through natural feeding, and irrigation practices, and it is far cheaper to use freshwater for industrial purposes. In many cases, freshwater resources, particularly rivers and lakes also perform recreational and transportation functions, while marine water resources are of vital importance, particularly for countries with seaward boundaries, providing the natural habitat for exploitable fishery resources.

Historically, water resources have played significant roles in the evolution of human society and civilisation. In Europe for instance, the Rhine valley, recognised as a locus of both co-operation and conflict was a primary nexus of economic growth (Sadoff and Wittington, 2002). In Africa, early civilisations such as those of the Nile valley and plains provide another classic example of how seasonal inundation provided water and increased soil fertility that encouraged and enhanced agricultural productivity. In the West African sub-region, the Senegal and Niger rivers played similar roles. In the same vein, the decline of some civilisations had been closely associated in part with problems of effective water management and utilisation. ${ }^{1}$ Water resources also have political and cultural dimensions, which dimensions ultimately determine human settlement patterns, economic structures and opportunities that are available to the entire population. In the African continent for example, there had been several migrations of peoples from one region to the other over the ages, influenced by water in terms of scarcity and availability, with the stronger groups of people generally tending to move towards and settle close to the great rivers and lakes.

In many African countries, as elsewhere, the demand for water has been on the increase in recent years (Sharma et al., 1996). This has been due to a number of factors. The critical factors include phenomenal increase in population, rising agricultural demand, urbanisation and associated water stress, as well as frequent droughts in the arid and semi-arid regions of the continent, where drought- induced water scarcities have brought social shocks on incipient fragile economies. The designing of an appropriate framework for the optimal exploitation, management and utilisation of Africa's water resources must of necessity be a fundamental policy imperative for the $21^{\text {st }}$ century, in line with the $7^{\text {th }}$ Millennium Development Goal, which encompasses the need 
to "ensure environmental sustainability through integrating the principles of sustainable development into country policies and programmes ... and halving by 2015 , the proportion of people without access to safe drinking water (ADB, 2002). ${ }^{2}$

This paper specifically examines Nigeria's water resources, in terms of resource profile and the strategies adopted over the years towards optimal exploitation, management and utilisation. The environmental implications of water resource use (by man and nature) are also examined taking into specific account the link to sustainable development. Against this background, the problems militating against effective management of the country's water resources are highlighted. The ultimate objective is to identify a number of critical factors, which must be taken into account in designing appropriate strategies for sustainable utilisation of the nation's water resources.

Following the introductory section above, the remaining part of the paper is divided into six parts, beginning with section 2, which presents the framework of analysis. Section 3 is concerned with analysis of the profile of Nigeria's water resources, and the role of government towards their effective utilisation. In section 4, we examine the interaction between water resources and environmental sustainability, while sections considers a sustainable framework for the management of Nigeria's water resources, and finally, section 6 concludes the paper.

\section{FRAMEWORK OF ANALYSIS}

In Nigeria, as in many other Sub-Sahara African (SSA) countries, water is generally regarded more or less as a nature-given resource. In the few urban centres where municipal schemes of water supply still function, water is perceived more as a semi-public good, and being characterised by weak non-rival and nonexcludable consumption, the majority of people have the implicit incentive to misuse and waste it. However, the form in which water is used, either in terms of consumption or production activities is not free in the strict economic sense. For instance, water that is treated for human consumption has a measurable economic value deriving from the scarcity value of non-naturegiven resources that are used in producing it. ${ }^{3}$

Essentially, the economist's view of consumptive use of water is that it occurs when one use of it makes it no longer suitable for subsequent desirable uses, except some extra cost is incurred. Using stream water for instance for waste disposal makes the use of the same water for recreational, fishing, or drinking purposes unsafe. Recreational use of the stream water requires certain biological purity characteristics, which are necessarily impaired by its pollution. The same holds for drinking water. To bring back the quality of water to its normal level, extra costs must be incurred.

We can also consider water as a unitary resource, since all water in the hydrological cycle forms part of one whole. Consequently, any intervention by man or nature, at or on one part of the cycle has a definite impact on another phase of the cycle. Excessive extraction of groundwater for instance has the potential of reducing base flows to rivers. The diversion of surface water may reduce the rechargeability of ground water, just as the discharge of wastewater affects water quality. And ultimately, water quality determines the dynamics of the ecology (Sharma et al., 1996), with its interrelated natural systems such as land and forests. Generally, as human interventions intensify through the effect of rapid population growth, poverty and poor land use practices, water ecosystems such as rivers can be fundamentally altered in terms of increased deforestation, soil erosion and runoff, as well as possible modification, in the long-run, of microclimates. The loss of vegetation for instance may contribute to loss of soil and water quality, impede river flows and increase sedimentation processes. It is within this context that the management of water resources should be ideally set within a broader framework of land use and the level of economic activities, with man and sustainable human development as the primary factors of concern.

It turns out that the poorest segments of society are the ones who have the least access to water, and incidentally, they are the ones who pay the most for water services, from the economic point of view. In the typical African urban centre for instance, the poorest communities are usually the last to be served by municipal water utilities - a situation that usually forces them to gather their own water often from polluted sources, with their health threatened by contaminated water and improper sanitation. They are also the ones who purchase water from 
vendors, oftentimes at prices higher than what is paid by the privileged that are connected to the municipal supply system. In the typical African rural community, particularly in arid semi-arid areas, it is the poor who are most affected by lack of access to water to support their livelihood through farming. They are also the ones that are most adversely affected by droughtinduced famines.

The scenarios painted above indicate that there is an intricate relationship between the availability of water for household consumption and other productive uses on the one hand, and the issues of health and disease, poverty reduction, food security, and hence sustainable development. Water of insufficient quantity and quality leads to water-related diseases. Inadequate rainfall and absence of irrigation facilities reduce agricultural production and threaten food security, and both factors work to intensify the problem of poverty. Understandably, the designing and implemen-tation of an appropriate water resources management strategy is of fundamental importance, in any meaningful efforts to reduce poverty, enhance food security and productive living, and enhance environmental sustainability and economic growth in Africa. Against the foregoing background, we now examine the profile of water resources in Nigeria.

\section{NIGERIA'S WATER RESOURCES}

This section is divided into three parts. The first subsection presents the country's water resources endowment, while the second is concerned with a review of policies directed at improving the quality of water resources, and their management and utilisation over the years. The third section assesses the effectiveness of the various policy measures.

\subsection{Water Resources Endowment}

The Nigerian freshwater environment consists of a number of rivers and their flood plains, streams, lakes and wetlands, with the rivers and streams relatively evenly distributed all over the country. Annual rainfall is however highly variable across the different regions, varying from about $250 \mathrm{~mm}$ in the extreme north of the country, to about $500 \mathrm{~mm}$ in the south. Rainfall constitutes a significant source of water, with the annual renewable total estimated at about 319 billion cubic meters during the mid1980s (Aminu, 2000; CBN, 2000). The distribution of average annual renewable water across the different hydrological areas (HAs) is as shown in Table 1.

As can be seen from Table 1, both the Benue (Upper and Lower) and Lower Niger HAs constitute the largest source of annual renewable water in Nigeria. The Niger river is of great significance in the management of water resources, not only in Nigeria, but also in other countries in the West African sub-region. It is one of Africa's 55 international rivers, traversing such countries as the Republic of Benin, Burkina Faso, Chad, Cote d' Ivoire, Guinea, Mali, Niger, Nigeria, and Sierra Leone. ${ }^{4}$ Within the context of co-operative management of water resources, it is important for us to note, that shared rivers have implications for the perception of water rights, as well as on the issue of national security and sovereignty. ${ }^{5}$

The Benue is another major river in Nigeria. Other than the Niger and the Benue, the country has well over 40 rivers and streams ( Orubu, 1995; Oboli, 1971; Majasan and Young, 1997). There are also the large lakes, including the Chad and Kaiji. The Nigerian sector of the Lake Chad has a total surface area of about 550,000 hectares, while the Kainji Lake, has a total surface area of about 127,000 hectares. These water bodies support a multiplicity of economic activities, including fishing, transportation and recreation. Most importantly, all these freshwater bodies are the source of drinking water for a large proportion of the population in areas where there are no public water supply facilities. The River Niger is also the major source of hydroelectricity

Table 1: Distribution of annual average yield of surface and ground water in Nigeria

\begin{tabular}{lcc}
\hline Hydrological area & $\begin{array}{c}\text { Average surface } \\
\text { water annual } \\
\text { yield } 10^{9}\left(\mathrm{~m}^{3}\right)\end{array}$ & $\begin{array}{c}\text { Average ground } \\
\text { water annual } \\
\text { yield } 10^{9}\left(\mathrm{~m}^{3}\right)\end{array}$ \\
\hline Chad Basin & 8.2 & 5.6 \\
North West & 22.4 & 4.3 \\
Upper/Lower Benue & 83.0 & 11.4 \\
West Littoral & 35.4 & 9.0 \\
Lower Niger & 85.9 & 13.4 \\
North Central & 32.4 & 8.2 \\
\hline Total & 267.3 & 51.9 \\
\hline
\end{tabular}

Source: Adapted from Aminu (2000) 
generation in the country and its delta is recognised as one of Africa's major wetlands. The Niger delta occupies the largest proportion of the total land area of the geographic southeastern part of Nigeria. It supports a wide variety of fish and other aquatic resources. It is also rich in petroleum and gas resources. ${ }^{6}$ The distribution of renewable freshwater and its allocation between domestic, industrial and agricultural uses are summarised in Table 2 for selected African countries, including Nigeria to provide a comparative frame of analysis

As shown in Table 2, average annual renewable freshwater in Nigeria in per capita terms is estimated at 2,310, 1,815, 1,982 cubic meters in 1990, 1991 and 2000 respectively. The figures compare favourably with what obtain for other relatively well-populated African countries such as Ethiopia, Egypt, Kenya, Tanzania and South Africa. As for total consumptive withdrawal, about $54 \%$ goes into agricultural production, while domestic and industrial uses account for about $31 \%$ and $15 \%$ respectively. This pattern of water resource utilisation is virtually common to all African countries, with the agricultural sector accounting for the largest proportion followed by industrial and domestic uses, in that order. Table 3 summarises actual water utilisation proportions for Nigeria over the period $1991-2001$. $^{7}$

As shown in Table 3, over the period 1991 2001, domestic consumption accounted for about $12.4 \%$ of the total volume of water available for consumption in Nigeria. $25 \%$ was consumed through industrial production, while agricultural production through irrigation accounted for about $34.2 \%$ of the total. The remainder of $28.2 \%$ is accounted for by wastages - the latter reflecting factors of misuse and runoffs. The bracketed expressions under columns 1 and 6 are the relevant annual growth rates for total available water volume and total land area in million hectares. Apart from the relatively large jumps in the annual increases in water volume recorded for 1999 and 2001, the data series indicates that total water available for consumptive did not generally record any significant increase over the period 1991 - 2001. Total land under irrigation also did not record any significant growth, as evidenced by a historical average annual growth rate of $0.68 \%$ for the period 1991 2001.

The role of water as a vital basic need of life as well as in supporting the process of development is recognised by government in Nigeria. Consequently, government, over the years, and at different levels has been concerned about designing the most appropriate strategy

Table 2: Water resources and withdrawal for selected African countries

\begin{tabular}{|c|c|c|c|c|c|c|c|c|}
\hline \multirow[t]{2}{*}{ Country } & \multicolumn{4}{|c|}{$\begin{array}{l}\text { Per capita annual internal } \\
\text { renewable water resources }\left(m^{2}\right)\end{array}$} & \multicolumn{4}{|c|}{ Annual freshwater withdrawals } \\
\hline & 1990 & 1998 & 2000 & Year & $\begin{array}{c}\text { Total } \\
\mathrm{Km}^{3}\end{array}$ & Domestic & $\begin{array}{l}\text { \% of Total } \\
\text { industry }\end{array}$ & Agriculture \\
\hline Benin & 5,480 & 1,751 & 1,670 & 1994 & 0.15 & 23 & 10 & 67 \\
\hline Burkina Faso & 3,110 & 1,535 & 1,466 & 1992 & 0.38 & 19 & 0 & 81 \\
\hline Chad & 6,760 & 2,176 & 1,961 & 1987 & 0.18 & 16 & 2 & 82 \\
\hline Cote d' Ivore & 5,870 & 3,265 & 5,187 & 1987 & 0.71 & 22 & 11 & 67 \\
\hline Ethiopia & 2,350 & 1,771 & 1,758 & 1987 & 2.21 & 11 & 3 & 86 \\
\hline Egypt & 30 & 43 & 34 & 1993 & 55.1 & 6 & 8 & 86 \\
\hline Gambia & 3,500 & 2,513 & 2,298 & 1982 & 0.02 & 7 & 2 & 91 \\
\hline Ghana & 3,530 & 1,607 & 1,499 & 1970 & 0.30 & 35 & 13 & 52 \\
\hline Kenya & 590 & 696 & 672 & 1990 & 2.05 & 20 & 4 & 76 \\
\hline Libya & 150 & 100 & 143 & 1994 & 4.60 & 11 & 2 & 87 \\
\hline Mali & 6,620 & 5,071 & 5,341 & 1987 & 1.36 & 2 & 1 & 97 \\
\hline Morocco & 1,190 & 1,071 & 1,058 & 1992 & 10.85 & 5 & 1 & 92 \\
\hline Niger & 1,970 & 346 & 326 & 1988 & 0.50 & 16 & 2 & 87 \\
\hline Nigeria & 2,310 & 1,815 & 1,982 & 1987 & 3.63 & 31 & 15 & 54 \\
\hline Rwanda & 870 & 965 & 815 & 1993 & 0.77 & 5 & 2 & 94 \\
\hline Senegal & 3,150 & 2,933 & 2,785 & 1987 & 1.36 & 5 & 3 & 92 \\
\hline Sierra-Leone & 38,540 & 34,957 & 32,960 & 1987 & 0.37 & 7 & 4 & 89 \\
\hline South Africa & 1,420 & 1,011 & 1,110 & 1990 & 13.31 & 17 & 11 & 72 \\
\hline Tanzania & 2,780 & 2,485 & 2,387 & 1994 & 1.16 & 9 & 2 & 89 \\
\hline Togo & 3,330 & 2,594 & 2,484 & 1987 & 0.09 & 62 & 13 & 25 \\
\hline Zimbabwe & 2,370 & 1,182 & 1,208 & 1987 & 1.22 & 14 & 7 & 79 \\
\hline African Continent & 5,994 & 5,209 & 4,832 & 1995 & 145 & 7 & 5 & 88 \\
\hline
\end{tabular}

Source: African Development Bank (2002) 
Table 3: Total volume of water available and utilisation, 1991 - 2001

\begin{tabular}{|c|c|c|c|c|c|c|}
\hline Year & $\begin{array}{c}\text { Total volume } P \\
\text { available } \\
\text { (billion } \mathrm{m}^{3} \text { ) }\end{array}$ & $\begin{array}{c}\text { Dentage share of } \\
\text { Domestic } \\
\text { use (2) }\end{array}$ & $\begin{array}{l}f \\
\text { Industrial } \\
\text { use (3) }\end{array}$ & $\begin{array}{l}\text { Irrigation } \\
\text { (4) }\end{array}$ & $\begin{array}{c}\text { Others } \\
\text { (5) }\end{array}$ & $\begin{array}{c}\text { Total land and } \\
\text { irrigation million } \\
\text { ha }(6)\end{array}$ \\
\hline 1991 & $4,223.8$ & 8.9 & 27.9 & 30.0 & 33.2 & 159.9 \\
\hline 1992 & 4,964.3 (1.8) & 8.7 & 23.8 & 30.0 & 37.5 & $204.9(2.8)$ \\
\hline 1993 & $5,115.0(3.0)$ & 12.2 & 24.4 & 30.0 & 32.8 & $250.0(2.2)$ \\
\hline 1994 & $5,120.0(0.1)$ & 13.0 & 24.5 & 45.0 & 17.5 & 297.6 (1.9) \\
\hline 1995 & $5,140.0(0.4)$ & 12.9 & 24.5 & 32.0 & 30.6 & $223.6(-2.5)$ \\
\hline 1996 & $5,150.0(0.2)$ & 13.0 & 24.6 & 34.0 & 28.4 & $227.5(1.7)$ \\
\hline 1997 & $5,159.0(0.2)$ & 13.2 & 25.0 & 35.0 & 26.8 & $229.3(0.7)$ \\
\hline 1998 & $5,159.0(0)$ & 13.2 & 25.0 & 35.0 & 26.8 & $229.3(0)$ \\
\hline 1999 & $5,675.8(10.0)$ & 13.2 & 25.0 & 35.0 & 26.8 & $229.3(0)$ \\
\hline 2000 & $5.675 .8(0)$ & 13.2 & 25.0 & 35.0 & 26.8 & $229.3(0)$ \\
\hline 2001 & $6,546.6(15.3)$ & 14.2 & 27.5 & 35.0 & 23.3 & $229.3(0)$ \\
\hline Average & (3.1) & 12.4 & 25.2 & 34.2 & 28.2 & $(0.68)$ \\
\hline
\end{tabular}

Source: Computed from Central Bank of Nigeria (CBN), Annual Report and Statement of Accounts, Several Issues. See also CBN (2000)

to address the situation. In the next subsection, we therefore examine the role of government in the management and utilisation of the country's water resources.

\subsection{The Role of Government in the Water Resources Sector}

Government policy on the water resources sector has been hinged on the need for a sensible and comprehensive development of the country's water resources to provide safe drinking water for the populace in both urban and rural areas, make water available for agricultural development through irrigation schemes, as well as the generation of electricity along the country's main watersheds. The earliest efforts

Table 4: Share of federal capital budget allocated to water supply (1991 - 2001)

\begin{tabular}{ccc}
\hline Year & $\begin{array}{c}\text { Allocation to water } \\
\text { supply(N million) }\end{array}$ & $\begin{array}{c}\text { As percentage } \\
\text { of annual federal budget }\end{array}$ \\
\hline 1991 & 83.8 & 0.02 \\
1992 & 71.7 & 0.01 \\
1993 & 63.6 & 0.12 \\
1994 & 197.5 & 0.6 \\
1995 & $2,579.4$ & 2.1 \\
1996 & $2,195.1$ & 14.9 \\
1997 & $2,786.2$ & 1.5 \\
1998 & $3,843.4$ & 1.5 \\
1999 & N.A. & N.A. \\
2000 & 14,318 & 2.2 \\
2001 & 64,761 & 7.2 \\
2002 & 30,200 & 3.3 \\
\hline
\end{tabular}

Source: Central Bank of Nigeria, Annual Report and Statement of Accounts, Several Issues by government, particularly at the central level to develop and manage the country's water resources predate the era of political independence. For example, during the decade between 1946 and 1956, the colonial administration expended about $15.1 \%$ of the country's total capital expenditure on water supply (Aminu, 2000), particularly in designated urban centres. Between 1957 and 1960, the share of water resources in total capital expenditure of the Federal Government was about $7 \%$.

The First National Development Plan (1962 - 1968) allocated N48.6 million representing $3.6 \%$ of the total planned capital investment expenditure to the development of water resources. The Second National Development Plan $(1970$ - 1974) allocated $\$ 148.6$ million to water resources development - representing $4.5 \%$ of the total planned investment. However, allocation to the sector was $\$ 930.04$ million representing $2.83 \%$ of total planned capital expenditure under the Third Plan (1975 - 1980), rising to $\$ 3.12$ billion under the Fourth Plan, representing $4.4 \%$ of projected total capital expenditure (Aminu, 2000). Table 4 summarises expenditure allocated by the Federal Government to water supply over the period $1991-2001$.

As can be seen from Table 4, allocations to improve the supply of water were generally low during the 1990 s - the only exception being in 1996 when the annual allocation increased by $14.9 \%$ over its 1995 level. However, capital allocation to water supply increased by $7.2 \%$ in 2001 over its 2000 level - an indication that the new democratic government ushered in 1999 did 
make some efforts to improve the supply of water through budgetary provisions - although the share of water resources in the total capital budget fell to $3 \%$ in 2002 . Under the current democratic administration, the thrust of water resources policy is to provide universal access to safe drinking water and adequate sanitation, with the availability of rural water supply projected to increase from its current level of $30 \%$ to $50 \%$ of the population by 2003 (FGN, 2000). In furtherance of its objective to increase the population's access to safe water, the Federal Government in the year 2003 has adopted a Presidential Water Initiative, with the ultimate goal of increasing water access in all state capitals, urban and semi-urban areas and rural communities to at least $75 \%$ by the year 2007 . This initiative is set as part of government's programme of poverty alleviation, integrated rural development, and job creation ${ }^{8}$.

Historically, the regional governments, and later state governments were responsible for the production and distribution of potable water in urban and semi-urban areas. By 1974, only the Western and Midwestern States had their own water corporations while in other states, the production and distribution of portable water were the responsibility of the Ministry of Works (CBN, 2000). ${ }^{9}$ However, by 1978 , all states in the Federation had established their own Water Boards. Earlier in 1976, the development of water resources had received a boost, by the creation of the River Basin Development Authorities (RBDAs) to provide water for irrigation purposes, as well for human consumption, particularly in rural communities. The RBDAs were relatively more active during the mid-1980s. In 1985, the RBDAs had about 32.6 thousand hectares (ha) under irrigation, sank 108 borehole and 8 earth dams. The respective achievements for 1989 were 67.9 thousand ha; 462 boreholes and 16 earth dams. During the period 1991 - 1996, the total area of land brought under irrigation by the RBDAs was 46.6 thousand hectares, representing only $16.9 \%$ of the cumulative total of 275.4 thousand hectares achieved for the period 1985 - 1996.

Under the Agricultural Development Projects (ADPs), the cumulative number of boreholes drilled country-wide over the period 1985 - 1996 was 53,499, with the total area of land brought under irrigation estimated at 85.6 million hectares, mainly through the Fadama Irrigation
Programme (Sharma et al; 1996). The Directorate of Foods, Roads and Rural Infrastructure (DFFRI) was also established under the Babangida administration in the mid1980 s, with rural water supply as one of its mandates. DFFRI did not however make any significant impact on water supply throughout the country, and in 1994, all water supply activities of DFFRI, were transferred to the Federal Ministry of Water Resources and Rural Development created in 1993. In 1993, the new Ministry, in collaboration with the Japanese International Cooperative Agency had prepared a National Water Resources Master Plan for the country. In that year, the Federal Government of Nigeria (FGN) and the European Community also sponsored the Middle Belt Water Supply Project, and the Water Resources Decree (No. 101) was also promulgated. The objective of the Decree was to effectively control and use the country's surface and groundwater and any other watercourses affecting more than one state, together with their beds and banks. Decree No. 101 of 1993 vested the powers of control and use of Nigeria's water resources in the FGN, and up to the early 2000s, these powers were effectively exercised through the activities of the Federal Ministry of Water Resources and Rural Development, which also co-ordinated the activities of the National Council on Water Resources. At the state level, the governments continued to run their own Water Boards/ Corporations. Some local government authorities have also made efforts at supplying water to the populace, particularly in rural areas.

The developments reviewed above are related more specifically to the development of freshwater resources. At the level of managing marine water resources, not much seems to have been done. This is quite understandable as the management of marine water resources has trans-national implications. Efforts have however been made to monitor the movement of toxic wastes into the country's shoreline and continental shelf. To this effect, in 1990, the Federal Government signed the Basle Convention on the control of transboundary movement of hazardous wastes and their disposal. International co-operation in the monitoring of transboundary movement of toxic wastes is through the Toxic Waste Dump Watch. In the year 1997 for instance, 10 alerts were received from South Korea, Japan, the USA and 
UK, to which the Federal Environmental Protection Agency (FEPA) - created in 1988 (merged with the Federal Ministry of Environment in 1999) promptly responded. Part of the responsibility of FEPA also included the monitoring of water quality, particularly of flows from industrial processes. ${ }^{10}$ Some efforts have also been made to protect the Lagos shoreline and manage the effects of sea inundation in the country's coastal zone (CBN, 2001). We assess the effectiveness of efforts of government in the next subsection with respect to both freshwater and marine water resources.

\subsection{Effectiveness of Water Resources Management Strategies}

As established from the foregoing subsections, it is clear that the major objectives of Nigeria's water resources development policy are two- fold. First is the need to increase the access of the population to safe water - for both drinking and industrial purposes, and second is to increase the supply of water through irrigation for agricultural purposes. Access to safe water is measured in terms of the proportion of the population who have an adequate quantity of water from an improved sources such as a household connection, public standpipe, borehole, protected well or spring or rain water collection. Reasonable access is defined as the availability of at least 20 litres of water per person per day, from a source of one kilometre of dwelling (World Bank, 2003a). In 1990, about $83 \%$ of the urban population was estimated to have access to safe drinking water. This however dropped to $78 \%$ in 2000 . For rural dwellers, the relative proportions were $37 \%$ and $49 \%$ respectively for the same periods (World Bank, 2003a).

The total volume of water available in 1999 was estimated at 5,675.8 billion cubic metres and remaining constant at this volume in 1999. However, in 2001, the estimated volume rose to 6,546.6 billion cubic metres, representing a range percentage increase of $15.3 \%$ between 1999 and 2001, with the total quantity of water for domestic consumption increasing in the aggregate from about $30 \%$ to $57 \%$ in the second half of $2003^{11}$. There are therefore indications that the efforts taken at improving the quantity available for consumptive use by Government since the advent of the new democratic administration in 1999 may be yielding some positive results - attributed largely to relatively enhanced absolute budgetary provisions. However, on a comparative scale, the situation of water supply seems to have improved more significantly for rural communities, than for urban centres. This may be interpreted as reflecting the preference of government towards improving the situation of water access for the rural population. Table 5, summarises statistics on access to safe water in selected African countries, including Nigeria.

Compared to such countries as South Africa, Egypt, Libya and Cote d' Ivoire, whose relative water access rates are higher than the African average for 1990 and 2000, only the rural population's access estimated at $49 \%$ for 2000 is higher than the African average, for Nigeria. In spite of substantial resources made available through grants and loans from external agencies such as the World Bank, African Development Bank and other agencies during the early 1990s (see CBN, 2000), particularly to develop water facilities in urban centres in the country, the largest proportion of Nigerian cities still do not have reliable public water supply facilities, and many residents produce water for consumptive use through individual boreholes or buy water

Table 5: Percentage of population with access to safe water in selected African countries

\begin{tabular}{|c|c|c|c|c|}
\hline \multirow{2}{*}{$\begin{array}{l}\text { Country/ } \\
\text { Population }\end{array}$} & \multicolumn{2}{|c|}{ Urban Population } & \multicolumn{2}{|c|}{ Rural } \\
\hline & 1990 & 2000 & 1990 & 2000 \\
\hline Benin & N.A & 74 & N.A & 55 \\
\hline Burkina Faso & N.A & 66 & N.A & 37 \\
\hline Cameroon & 78 & 78 & 32 & 39 \\
\hline Chad & N.A & 31 & N.A & 26 \\
\hline Cote d' Ivoire & 97 & 92 & 69 & 72 \\
\hline Gabon & N.A & 95 & N.A & 47 \\
\hline Gambia & N.A & 80 & N.A & 53 \\
\hline Ghana & 85 & 91 & 36 & 62 \\
\hline Kenya & 91 & 88 & 31 & 42 \\
\hline Mali & 65 & 74 & 52 & 61 \\
\hline Mauritania & 34 & 34 & 40 & 40 \\
\hline Niger & 65 & 70 & 51 & 55 \\
\hline Nigeria & 83 & 78 & 37 & 49 \\
\hline Ruanda & N.A & 60 & N.A & 40 \\
\hline South Africa & 99 & 99 & 73 & 73 \\
\hline Tanzania & 76 & 90 & 28 & 57 \\
\hline Togo & 82 & 85 & 38 & 38 \\
\hline Zimbabwe & 99 & 100 & 69 & 73 \\
\hline Egypt & 97 & 99 & 92 & 96 \\
\hline Libya & 72 & 72 & 68 & 68 \\
\hline Morocco & 94 & 98 & 58 & 56 \\
\hline All Africa & 84 & 85 & 49 & 45 \\
\hline
\end{tabular}

Sources: World Bank (2003a, 2003b), World Development Indicator, and African Development Indicators. 
at high prices from vendors.

As for water supply for agricultural activities through irrigation, the records have not also been impressive. For example, total land under irrigation in the country has remained at 229.3 thousand hectares annually for the period 1997 - 2001, while the total volume of water consumed through irrigation fell from 2.29 billion cubic metres in 1997 to 1.99 billion cubic metres in 2001 (CBN, 2001) However, it is important to note that the Fadama component of the World Bank - supported ADPs in the country, particularly during the 1980s was relatively successful in helping farmers to increase water use for dry season crop production. The Fadama experiment allowed irrigation on about one or two hectares of land at an average cost of between US $\$ 350$ and US $\$ 700$ per hectare, with drilled tube wells, and water pumps made available to farmers at subsidised cost. By the early 1990s, the project had over 50,000 pumps operating nation-wide, with $90 \%$ success rate in terms of farmer adoption (Sharma et al.1996). However under the current administration, significant attention has not been paid to the essentially stakeholder strategy Fadama programme.

With respect to the management of coastal and marine water resources in the country, the efforts of Government have been complemented in the past by Non-Governmental Organisations (NGOs), particularly in the area of preventing desertification and pollution control of coastal waters, and protection of coastal shorelines from the effect of sea level rise and erosion. ${ }^{12}$ There is however much that is yet to be done in this area. ${ }^{13}$

A number of factors militate against efficient exploitation of Nigeria's water resources. Critical among these are the existence of a multiplicity of agencies responsible for the production of water and its distribution to users, and the absence of an efficient mechanism to fully maximise the willingness of the populace to pay for water services, both in urban centres and rural communities. A number of past water supply schemes, particularly under the DFRRI and RBDAs also did not take into account the need to involve all stakeholders, particularly the ultimate users in the management and maintenance of water facilities provided, thus leading to unsustainability of project benefits. Lack of adequate project preparation, particularly for city-wide water supply schemes had also led in the past, to project abandonment and failure. ${ }^{14}$ And then there is the problem of inadequate funding of water resources development projects - although there are indications that during the first four years of the present democratic administration, the water resources sector received relatively more significant attention than was the case during the period 1991 - 1995 , and between 1997 and 1999. On a comparative scale, the country is however still relatively far away from universal access to water. As admitted by the Federal Minister of Water Resources, Alhaji Muktar Shagari, "despite the large volume of rainfall, streams and lakes, the true position is that there is scarcity of fresh or wholesome water for human consumption in the country". ${ }^{15}$ The new Presidential Initiative on water is in itself an admission of the fact that much remains to be done in terms of progress towards universal access to water in the country.

As already noted, water resources utilisation is closely linked to other subsystems of the human and physical environments in an intricate manner. For example, water supply shortages, particularly in urban centres, and the pollution of watercourses, could put a negative stress on the sanitation status of the populace, leading to the outbreak of water-borne diseases. Pollution of watercourses can also adversely affect fish population, and hence sustainable livelihood of people who depend on them for sustenance. The acknowledgement of this fact is responsible for why many governments in African countries have undertaken Development Action Plans, which, as a rule have emphasised the importance of water in environmental management. In the next section, we consider briefly, the interaction between water resources and the environment, and how this interaction affects sustainable development.

\section{WATER RESOURCES, ENVIRONMENTAL QUALITY AND SUSTAINABLE DEVELOPMENT}

We first of all consider the key environmental issues. Thereafter, we examine their implications for sustainable development.

\subsection{The Key Environmental Issues}

Of all environmental resources, water is probably the one that is most abused through 
human activity. For example, the emission of organic pollutants as a result of industrial activities is responsible for rapid deterioration of water quality, with definite health consequence for the human population. The total effect of deterioration of water quality includes industrial, recreational and fishing diseconomies (Kneese and Bower, 1979). Scarcity of water, particularly in urban centres complicates the problem of sanitation, thereby posing a threat to public health. In rural communities without access to safe water, and where drinking water is sourced from polluted streams and stagnant water bodies, there has been marked incidence of water-related diseases such as cholera, river blindness, guinea worm infestation, all of which impose substantial welfare loss on society (Listorti, 1996).

It does appear that the degradation of all categories of environmental resources records intense deterioration during the initial stages of the development process but over time substantial economic growth should lead to better environmental quality. This argument has been coined in the so-called Environmental Kuznets curve (see for example Grossman and Krueger, 1991; 1995; Shafik, 1994; Vincent et al. 1997; Harbaugh et al., 2000; Magnani, 2000; Boyce, 2003). However, it can be argued that economic growth alone does not provide the sufficient condition for improvement of environmental quality on all fronts, thus justifying environmental policy intervention at all stages of the development process (Orubu, 2003; Orubu et al. 2002). Thus given the linkage between economic and environmental processes, the identification of the specific environmental issues incidental to the exploitation and utilisation of Nigeria's water resources is justified. This should provide an appropriate analytic anchor on the basis of which an integrated framework for the management of water resources could be developed.

There are a number of specific invironmental issues relating to the Nigerian water resources. First, there is the problem of emissions of industrial pollutants from industrial sources, with the main polluting substances identified to include organic matter, metals, minerals, sediments, bacteria and toxic chemicals. Estimated emissions of organic water pollutants in Nigeria in 1980 amounted to $72,082 \mathrm{~kg}$ per day, and this rose to $82,477 \mathrm{~kg}$ per day in 2000 , representing $14.4 \%$ increase over the period.
This places the country as the third heaviest water polluter in Africa in 1980, and the fourth in 2000 (World Bank, 2003a). Inadequate water supply and inappropriate urban planning and management strategies in Nigeria have also compounded the problem of access to sanitation, thereby increasing health risk from water-related epidemics. The proportion of the population with access to adequate sanitation facilities during the period $1982-88$ is estimated at $62 \%$. This rose marginally to $63 \%$ in 2000 , compared to such countries as Cameroon, Egypt, Lesotho, Libya, South Africa with access estimated for 2000 at $92 \%, 94 \%, 92 \%, 97 \%$ and $86 \%$ respectively (ADB, 2002). At present, there are no wellfunctioning municipal water treatment plants in the cities. The implication of this is that all domestic, commercial and industrial wastewater is discharged directly into open drains. Where these drains go into natural water bodies, they have been known to decrease dissolved oxygen levels, with adverse effects on fish and other aquatic life.

Dredging activities on rivers and watercourses also have adverse consequences for the environment. Dredging activities are usually undertaken indiscriminately, thereby leading to unstable upper crust structure of adjoining human settlements. Indiscriminate sandmining in the country has in many instances led to stresses on road structures such as bridges. Although under the appropriate statutes, there is the requirement for the conduct of Environmental Impact Assessment (EIA) studies for dredging projects, the activities of sandminers are not usually checked. Indiscriminate sandmining activities also increase the risk of flooding in vulnerable topographies.

Pollution, particularly by oil industry activities has continued to pose a serious threat to fragile aquatic ecosystems of the Niger Delta area, where the largest proportion oil exploration and production activities takes place in the country. Major spills of crude petroleum into the Niger Delta ecosystem have been known to have adversely affected the mangrove ecology and fish population in the area, thereby negatively impacting the economic livelihood of the people (Ekuerhare and Orubu, 1996; Orubu et al., 2002) and the survival of non-timber forest products (Orubu, 1999).

The problems highlighted above are essentially man-induced. There are other 
environmental consequences of water resources, which are nature-induced, such as those caused by erosion due to unimpeded run-offs from rainfall and floods, including sea level rise. The cost of protecting the coastline against erosion, which is increased by the threat of global sea level rise will be enormous. The World Bank (1995) had estimated that in Nigeria, a one meter sea level rise could flood about $18,000 \mathrm{~km}^{2}$ of land, and damage economic assets worth billions of US dollars, and force the relocation of up to 3.7 million people - putting the moderate cost of protecting a fraction of the coastline against inundation at US $\$ 3,162$ billion!

During the early 1980s an exotic species of plant, Eichhornia crassipes commonly called Water Hyacinth, found its way into the Nigerian marine environment, and between 1984 and 1991 , spread fast over a distance of $800 \mathrm{~km}$ from Lagos to Akwa-Ibom State. The water hyacinth weed spreads very quickly, and makes rivers difficult to navigate. The weed has also been found to be a potential vector of disease since it transports molluscs and insects easily across countries. The environmental issues related to water resources discussed above are not exhaustive. However, the discussion provides an adequate point of departure for us to examine the connection between the sector and sustainable development.

\subsection{Water Resources and Sustainable Development}

Development is sustainable if current efforts directed at improving human welfare do not result in current distributional inequities or jeopardise the developmental possibilities of future generations. It is a development paradigm set within the early 1980s, and strongly popularised by the World Commission on Environment and Development (WCED), with the view that if economies are well-managed in an environmentally-sensitive way, growth and development could occur without putting undue stress on the world's environmental resources. Thus, technological advancement, sensible environmental conservation and protection, as well as good economic management practices provide the means of obtaining sustainable development (Pearce and Warford, 1993).

Since the 1980s, many countries, both industrial and developing, have therefore adopted holistic development strategies, which recognise the need to marry economic policy with sound environmental management practices, and that sustainable development is significantly contingent on an efficient system of managing environmental resources (Jaganathan and Agunbiode, 1990; Ihedioha, 1999). Water resources are among the resources to be optimally exploited and managed, in order for the development process to be sustainable. This view has been strongly propagated by the International Union for the Conservation of Nature, the World Bank, the United Nations Development Programme (UNDP) and other United Nations initiatives such as the United Nations Environmental Programme (UNEP) and other conventions on the environment (see Orubu, 2000).

It turns out that man is at the centre of the quest for sustainable development since any alteration of the environment affects man - for better or for worse. In relation to water resources, the interaction between their exploitation, use and the environmental consequences thereupon, whether such consequences are man - or nature - induced arise from the following:

(i) effects on man as a result of alteration of water quality and quantity

(ii) effect of distortion of hydrological balances that are man - or nature - induced, such as over-exploitation or prolonged drought or dry season, or desertification and evapotrans-piration, with adverse consequences on sustainable livelihoods and food security;

(iii) threat on human settlements as a result of unimpeded runoffs, erosion and sea inundation (the latter could be due to the phenomenon of global warming);

(iv) intensification of the vicious circle relationship between poverty and environmental degradation, which drives the vulnerable segments of society into deeper depths of poverty.

(v) unsustainable exploitation, through inappropriate havesting practices of life in/ on water (of both plants and animals) has the potential of leading to biodiversity loss, with adverse consequence on ecological balance. This fear is becoming real in the mangrove ecology of the country's maritime states;

(vi) water hyacinth infestation, particularly in the maritime states of Nigeria has signi- 
ficantly impeded navigation and fishing activities, thereby adversely affecting sustainable livelihoods of artissanals. The World Bank (1995) had estimated that it could cost an average of US $\$ 50$ million annually to control the weed in Nigeria, and that it negatively affects about 5 million households! And finally;

(vii) through the effects of water resources exploitation projects that change the physico-climatic characteristics of existing watersheds. The damming of the Niger at Kainji has, for instance reduced the volume of floodwater in the south-eastern part of the country, particularly the Niger Delta, and this has adversely affected long established migratory movement of fish from the upper regions of the Niger.

Given the foregoing, the most appropriate framework for the design of Nigeria's water resources management strategy is to blend elements of economic, hydrological and environmental policy, if the goal of sustainable development is to be achieved as we enter the $21^{\text {st }}$ century.

\section{APPROPRIATE WATER RESOURCES MANAGEMENT STRATEGY: THE WAY FORWARD}

As already shown in preceding sections of this chapter, Government over the years has shown significant concern over the exploitation of the country's water resources, and this is amply demonstrated by its involvement in the production and distribution of water for various forms of consumptive use - not only at the federal level, but also at lower tiers of government. Although there are indications that the current democratic administration, particularly during its first four years made more concerted efforts, particularly through enhanced budgetary allocations to the water resources sector compared to what obtained generally in the first quinquenium of the decade of the 1990s, there is still much to be done.

First there is need to move up the water access rating to cover a larger proportion of the population as well as the number of people who have access to modern sanitation, in order to enhance the quality of life. There is also the need to pay greater attention to increasing the supply of water for irrigation purposes, in areas of less rainfall and those susceptible to drought, as well as protecting vulnerable habitats from sea erosion and the possible adverse effects of sea level rise.

The logical framework of the strategy to be adopted must recognise the need for the interdependence between resources sustainability and the development process. The critical elements of the strategy should necessarily find anchor in the broad objective of the country's National Policy in the Environment, which recognises the need to:

- Secure for all Nigerians, a quality of environment that is adequate for human wellbeing.

- Conserve and use all environmental and natural resources for the benefit of present and future generations.

- Restore, maintain and enhance ecosystems and ecological processes which are essential for the functioning of the biosphere, and to preserve biological diversity and by upholding the principle of optimum sustainable yield in the use of living natural resources and ecosystem. These objectives are no doubt relevant to the management of water resources to ensure sustainable exploitation, and are consistent with the Dublin Statement from the International Conference on Water and the Environment as well as Agenda 21 of the United Nations Conference on Environment and Development (see World Bank, 1993).

The strategic interventions required to ensure sustainable and equitable use of water resources will include the building of local capacity and human resources in the area of water resources management and the involvement of all relevant stakeholders and the building of awareness on the dynamics and economics of water resources. It will also require the establishment of mechanisms for co-operation among the different agencies and interest groups concerned with the management and use of water resources. Institutional strengthening and a sound regulatory framework are also essential to support long term national investment directed at optimal exploitation of water resources, while a reliable hydrological data base is a sine qua non for such long-term planning.

On a bit-by-bit basis, the optimal strategy choice must give due consideration to the subsidiary principle in the management of common property resources, by decentralising 
responsibility for the production and distribution of water for consumptive uses; the need to accept the corollary of stakeholder participation in the design and implementation of water supply schemes; pricing water resources efficiently to reflect calculations of willingness to pay by consumers and experimenting with mass private sector participation in the production and supply of water for various forms of consumptive use. There is also the need to strengthen managerial efficiency of public provisioning to ensure a competitive leverage for the water market in addition to the provision of supportive infrastructure for urban and country planning to integrate the production of water with sound sanitation practices. Genuine efforts must also be made to develop a credible legal structure to deal with cases of wilful destruction of water facilities. For shared water resources an appropriate framework must be put in place to develop co-operative water resources manage-ment schemes among riparians in order to avoid and/or resolve water resources - related conflicts more easily. There is also the need for adequate preparation of water development projects properly before implementation, and the reduction of dependence on external resources by adopting simple technologies, developing local skills for operation of water schemes and creating appropriate incentive environment for the emergence of local manufacturers of water equipment and chemicals. Most importantly the time has come to involve the Nigerian private sector in the production and general distribution of water, particularly in urban centres, within the general framework of an integrated urban planning model.

\section{CONCLUSION}

In this paper, we have examined the Nigerian water resources sector, outlining its key features and the efforts made by Government over the years to step up the supply of water for various consumptive uses. The efforts of government were channelled mainly through the instrumentality of the development plan, the rolling plan and the annual budget of government under the agency of different intervention institutional structures such as the RBDAS, ADPs, DFRRI and the Ministry of Water Resources and Rural Development.

By and large, the proportion of the Nigerian population with access to safe water and sanitation is relatively low, compared to some other African countries such as South Africa, Egypt, Libya, Morocco, while the area of land under irrigation since the 1990s has remained virtually constant. Although there are indications that the current democratic administration, particularly in its first three years showed relatively more concern for the optimal exploitation of the country's water resources through higher absolute budgetary allocations, a lot more remains to be done in order to improve access of the population to safe water. The major argument advanced by the author is that because of the intricate linkage between water resources and environmental sustainability which is crucial to enhancing the quality of life of the poor in particular, there is need to frame water resources management strategies within the context of sustainable development principles. Essentially, the management of water resources in the country has been almost an exclusive responsibility of government. The time has therefore come to seek the co-operation of all the relevant stakeholders, including NGOs, the private sector and community-based organisations (CBOs) in a co-ordinated manner towards sustainable exploitation of the country's water resources.

\section{NOTES}

1. In the old land of Mesopotamia for example, there was the problem of siltation of irrigation canals. In the Indus region, there was the problem of salinisation. Today, there are a number of coastal regions that are threatened by sea encroachment.

2. The Millennium Development Goals are essentially a refinement of the International Development Goals derived from several agreements and resolutions of the United Nations Conferences held during the 1990s. For a summary of the eight Goals, see ADB (2002, p.1).

3. Man may however decide to consume water in its raw state, or simply do so because there is no choice, but this is not usually without dire health consequences (see Seneca and Tausig, 1984).

4. See Sadoff et al (2002: Pp 59-76).

5. Sadoff et al (2002 p.7) in particular note that this factor must be taken into account in designing sustainable water resources management strategies in Africa.

6. The Niger Delta covers a total landmass of about 20,000 square kilometres. For a description of the physical characteristics of the Niger Delta, see Orubu (1999), and Ekuerhare and Orubu (1996).

7. I am grateful to Mr. Christopher Ehinomen of the National Centre for Economic Management and Administration (NCEMA), for sourcing part of this table at short notice.

8. See The Guardian, Tuesday, 20/9/03

9. These figures are computed from several issues of Central Bank of Nigeria Annual Report and Statement of 
Accounts.

10. FEPA was merged with the Federal Ministry of Environment in 1999.

11 See The Guardian, Tuesday, 22/9/03.

12. The Nigerian Conservation Foundation and the Ford Foundation are examples of NGOs that have been very active in this area (see CBN, Annual Report and Statement of Accounts, 1997 . Others such as the Nigerian Environmental Study Team (NEST) and the Niger Delta Wetlands Centre have also been active through research and advocacy.

13. The World Bank (1995) had estimated the cost of protecting large proportion of the country's shoreline from sea level rise (of one metre) at US $\$ 3,162$ billion.

14 The World Bank - supported water supply scheme in the early 1990 s suffered this fate in many states. Delta State is a typical example.

15. See The Guardian, Tuesday, 22/9/03

\section{REFERENCES}

African Development Bank (ADB).: Gender, Poverty and Environmental Indicators on African Countries, 2002 - 2003, Vol. III, Abidjan, Development Research Department (2002).

Andreomi, James and Arik Levinson.: The simple analytics of the environmental Kuznets curve. Working Paper 6739, NBER, Cambridge, MA. (1998).

Aminu, F. T.: Natural resources and land use. Workshop on Environment and Sustainable Development, NCEMA, Ibadan August (2000).

Awopegba, P. O.: Overview of the planning and management of the social services sector in .Nigeria. Workshop on Planning and Management of the Social Services Sector, NCEMA, at Jos, May (2001).

Boyce, James K.: Inequality and environmental protection. Programme on Development and Peace-Building, Politica Economy Research Institute, University of Massachusetts, Amherst (2003)

Central Bank of Nigeria: The Changing Structure of the Nigerian Economy. Lagos, Realm Communications (2000).

Central Bank of Nigeria, Annual Report and Statement of Accounts, December 2001 and several other issues.

Ekuerhare, B. U. and Christopher O. Orubu: Economics of the Niger Delta, Report of the Economics Specialist, NDES Phase I, Port Harcourt, June (1996).

Federal Government of Nigeria: Obasanjo's Economic Policy Direction, 1999- 2003. The Presidency, Abuja (2000).

Grossman, G. M. and A. B. Krueger: Environmental impacts of North American Free Trade Agreement. NBER Working Paper No. 3914, National Bureau for Economic Research, Cambridge, Mass. (1991).

Grossman, Gene and Ala Krueger: Economic growth and the environment, Quarterly Journal of Economics, 110: 353 377 (1995).

Harbaugh, William, Arik Levinson and David Wilson: Reexamining the empirical evidence for an environmental Kuznets curve, NBER, Working Paper 7711, Cambridge, MA. (2000)

Ihedioha, D.: National environmental strategies. Paper presented at Workshop on Economic Management and the Environment, NCEMA, Ibadan November (1999).

Jagannathan, N. Vijay and A. Agunbiade: Poverty-environment linkages in Nigeria: issues for research. Workshop paper 1990 -7. World Bank, Environment Department (1990).

Kneese, A. V. and Bower (1979). Environmental Quality and Residuals Management. John Hopkins University Press, Baltimore (1979).

Listorti, J. A.: Bridging Environmental Health Gaps, Vol. I 2. Draft. Corrce Beach, Washington D.C. (1996).

Magnani, Elisabetta: The environmental Kuznets curve, environmental protection policy and income distribution, Ecological Economics, 32(3): 431-443 (2000).

Majasan, J. A. and C. T. Quinn Young: A Visual Geography of Nigeria. Ibadan Evans Publishers, Ibadan (1977).

Oboli, H..N.: Outline Geography of West Africa. Lordin George \& Co Ltd., Ibadan (1970).

Orubu, A. O.: Certificate Geography for Nigerian Schools, Febum Press, Ughelli (1995).

Orubu Christopher, O.: The exploitation of non-timber forest products in the Niger delta: Problems and prospects. Technical Paper, NDES, Port Harcourt, January (1999).

Orubu, C. O.: An overview of sustainable development. Training Programme on Environment and Sustainable Development, NCEMA, Ibadan August (2000).

Orubu, Christopher O.: Using transportation control measures and economic instruments to reduce air pollution due to automobile emissions, Journal of Social Science, Forthcoming (2003).

Orubu, Christopher O.: Adeyemi Fajingbesi, Ayodele Odusola, Nelson O. Magbagbeola: Environmental regulations in the Nigerian petroleum industry: Compliance and implications for sustainable development." $A C B F /$ NCEMA Draft Monograph (2002)

Pearce, D. W. and J. J. Warford: World Without End: Economics Environment and Sustainable Development. Oxford University Press/World Bank (1993).

Sadoff, Claudia W.; Dale Whittington and David Grey: Africa's International Rivers: An Economic Perspective. The World Bank, Washington D.C. (2002).

Seneca, J. J. and Tausig, M. K.: Environmental Economics. Prentice Hall, Englewood Cliffs (1984).

Sharma, Naranda, P.; T. Damhaup and Associates: African Water Resources: Challenges and Opportunities for Sustainable Development, (Technical Paper No. 331, Africa Technical Department Series). The World Bank, Washington D.C. (1996).

Vincent, Jeffrey R; Rozah, Mohameed Ali and Associates: Environment and Development in a Resource-Rich Country: Malaysia under the New Economic Policy, Harvard Institute for International Development (1997).

World Bank: Defining an Environmental Development Strategy for the Niger Delta, Vol. II, Industry and Energy Operations Division, Washington D.C. (1995).

World Bank: World Development Indicators. Washington D.C. (2003a)

World Bank: African Development Indicators. Washington D.C. (2003b)

World Bank: Water Resources Management. Washington D.C. (1993)

World Commission on Environment and Development (WCED): Our Common Future. Oxford University Press, Oxford (1987). 